\title{
Lika: Demographic Development under Peripheral Conditions
}

\author{
Dane Pejnović
}

\begin{abstract}
Lika is the most notable example of a periphery and also the most problematic region in Croatia. This work represents research into the region's demographic development under the conditions of Croatia's polarized development up to the beginning of the 1990s and the wartime and postwar events during the last intercensus period. The spatial scheme of analysis adheres to the sub-regions and contemporary local government units. The results show that Lika and all of its sub-regions were beset by demographic devastation already during the 1980s. In the current period, it is characterized by extremely inauspicious demographic features, which seriously brings into question the possibility of revitalizing this region.
\end{abstract}

Key words: Lika, periphery, regional development, demographic development, migration balance, natural population trends, depopulation

\section{Lika: demografski razvoj u uvjetima periferije}

Lika je najizrazitiji primjer periferije i najveće problemsko područje Hrvatske. U radu je istražen demografski razvoj regije u uvjetima polariziranog razvoja Hrvatske do početka 1990-ih godina te ratnih zbivanja i poraća u posljednjem međupopisnom razdoblju. Prostornu shemu analize čine subregije i suvremene jedinice lokalne samouprave. Rezultati pokazuju da su Lika i sve njezine subregije bile zahvaćene demografskim izumiranjem već 1980-ih godina. U suvremenom razdoblju karakteriziraju je krajnje nepovoljna demografska obilježja, što ozbiljno dovodi u pitanje mogućnost revitalizacije tog prostora.

Ključne riječi: Lika, periferija, regionalni razvoj, demografski razvoj, migracijski saldo, prirodno kretanje, depopulacija

\section{INTRODUCTION}

The spatial concept of Lika pertains to the traditional region in the southeastern section of Highland Croatia, between the mountains of Velebit, Mala Kapela and Plješivica, and the upper course of the Una River. Although it is situated almost at the geometric center of the country, its interspatial position between Croatia's leading living hubs, it is simultaneously the most drastic example of a peripheral zone, or, simply put, periphery. The region's spatial reality is clearly shown in the imbalance between its surface area and share of the country's population: Lika covers approximately $5,280 \mathrm{~km}^{2}$, which is $9.3 \%$ of Croatia's total territory; however, in 2001 it had a population of 45,075, which is only about $1 \%$ of the country's population. 
There are several reasons dictating the need the examine Lika's recent demographic development. First, as a rural periphery and Croatia's most problematic region, this area has been beset by an intense rural exodus over the past decade, which has had deep, unfavorable repercussions on the age structure and natural population trends. Second, due to the extreme ethnic dichotomy and wartime operations, this was one of the country's worst-hit regions during the war. Third, due to the multiple importance of Lika to the spatial/functional integration and stable development of Croatia, the appropriate planning measures will have to be undertaken with the objective of revitalizing this portion of the national territory. And it is precisely geography, as the preeminent geospatial discipline, that should play a major role in devising the most suitable model for development and functional organization in this region.

Lika brings together all of the most typical aspects of the classical periphery like no other region in Croatia. Besides its geographic 'marginality,' a periphery is characterized by explicit economic dependence on developed urban centers as the cores of more complex development. In such spatial/economic organization, hubs of polarized development began to stand out with increasing concentrations of economic activities and capital, and thereby with greater opportunities for innovation and development, as opposed to a periphery which, due to limited resources and scant innovation opportunities, is characterized by slower growth and lagging development. This is directly reflected in the spatial flows of capital, raw materials and other goods, and labor force migration from the periphery to core areas (Koči-Pavlaković, 1996).

Such immigration of the active working population results in reduced labor potential in peripheral areas, and this in turn leads to even greater stagnation in the country's regional development. Since immigration largely encompassed the younger population (youths and younger generations of older age groups), this is both directly and indirectly (through the aging and natural decline processes) reflected in even more intense reduction of the number of inhabitants in the periphery. This high degree of interdependence between spatial/ developmental disparities and population trends means that demographic development is an indirect but reliable indicator of relative differences in the level of development of individual sections of the national territory.

It is therefore understandable that spatial disparities in demographic development in Croatia have been the subject of great interest in both geographic and economic research. Among the relatively large number of works dealing with demographic development in the Croatian periphery, a more comprehensive approach can be found in studies by I. Nejašmić (1991) and I. Turčić (2001). ${ }^{1}$ A work by D. Pejnović (2004) provides a closer examination of the interdependent influence of depopulation and regional development in contemporary counties during the 1961-2001 period. Unfavorable change in population dynamics in the Croatian periphery by the beginning of the 1990s are demonstrated to the fullest extent in a work by M. A. Friganović (1992). Among recent research into Croatia's demographic and regional development, works by A. Akrap (2002), I. Nejašmić (2003) and M. Sić (2003) are particularly relevant for an understanding of the distribution, dynamics and structure of populations in peripheral zones. The negative tendencies of demographic development in Lika up to the beginning of the 1990s are presented in a work by D. Pejnović (1991), while 
the potential for revitalization of such depopulated and extremely war-stricken regions of Croatia is examined in another work by the same author (1996).

Consideration of demographic development in Lika under peripheral conditions imposes the need for research into trends in the number of inhabitants, and population structure and dynamics of the area being observed since the beginning of Croatia's polarized development. The work should provide answers to some specific issues, such as, for example: 1. developmental succession of depopulation and general population trends up to the 1990s, 2. the impact of wartime events in 1991-1995 on the region's demographic development, and 3. the crisis features of the current settlement structure as an aggravating factor for Lika's regional development and revitalization.

Based on empirical knowledge and the results of prior research into the topics and areas covered in this work, it is possible to present the following working hypotheses:

1. from the end of World War II to the beginning of the 1990s, demographic development in Lika proceeded under the express impact of immigration;

2. immigration was caused by ongoing and intense stagnation of this area in Croatia's regional development and the non-development of its principal central settlement (Gospić) as a potential core for gathering by the local population;

3. immigration left behind deep, unfavorable repercussions on natural growth and the population's biological structure by the beginning of the 1990s;

4. due to the historically-conditioned heterogeneous ethnic composition of the population, Lika was among the regions of Croatia worst hit by the war;

5. inherited demographic trends by the beginning of the 1990s and the repercussions of war were cumulatively reflected in the highest depopulation among Croatia's regions during the last intercensus period, 1991-2001, and

6. the small population, with extremely unfavorable dynamic and structural features, is reflected in the continual decline in labor potential, which leads to further, even more drastic stagnation in Croatia's regional development and generally brings into question (demographic and economic) revitalization of that part of the country.

\section{METHODOLOGY, PERIODIZATION AND SPATIAL STRUCTURE OF ANALYSIS}

The basis for selection of methodological approaches to this work entailed the pattern of Croatia's demographic development during the second half of the twentieth century. This development proceeded under the overriding influence of polarized development and the regional disparities it caused. The altered spatial relations that accompanied this process caused the increasing dependence of the rural periphery on polarized development hubs. This manifested itself particularly in the labor function, whose concentration in urban centers was accompanied by an intense rural exodus, with long-term negative consequences in the demographic and regional development of the periphery. 
Given its conditionality, Lika's demographic development can be most adequately examined within the framework of the theoretical model for regional development. According to this model, spatial-developmental disparity is the result of cumulative causation, wherein economic forces tend to deepen rather than reduce disparities in regional development (Witherick et al, 2001). Developed regions become progressively more advanced because they attract investments, innovation, better services and so forth. In contrast, less developed regions are characterized by inverse development in a downward spiral. Negative developmental processes create further unemployment, encourage emigration and reduce investor confidence. This chain of consequences for peripheries can be defined as a vicious cycle that incorporates two causal problematic circles, labor migration and investment (Fig. 1.)

a)

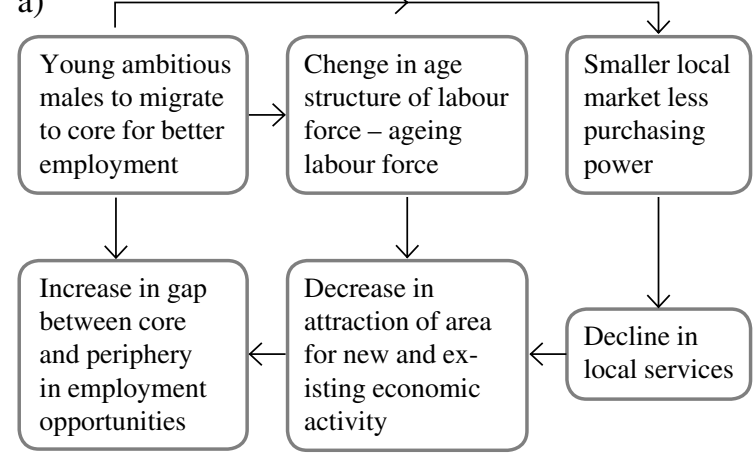

b)

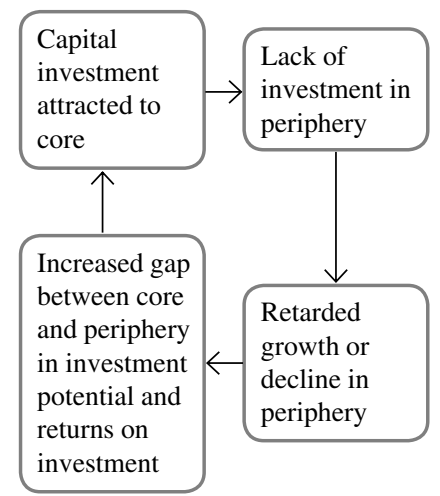

Fig. 1. Vicious circles or downward spirals typical of the periphery (a) labour migration, (b) investment Sl. 1. Začarani krugovi ili silazne spirale tipični za periferiju (a) radne migracije, (b) investicije

Based on the various causes of immigration and their spatial effects, when examining Lika's demographic development, it is justified, and in fact necessary, to distinguish different periods: the first, up to the mid-twentieth century to the beginning of the 1990s, and the second, actually the last intercensus period, 1991-2001. The first is characterized by continuity in socio-geographic development, wherein immigration was first and foremost caused by the features of the periphery, i.e. lagging regional development. The second was, on the other hand, marked by a drastic developmental discontinuity, wherein the fundamental impact on demographic development was exerted by wartime events from 1991 to 1995, and the direct and indirect consequences of war. This was also used to designate the fundamental periodization in this work.

In line with the object study (population), the basic documentation for the work will be the results of censuses during the period from 1953 to 2001. Here it should be noted that due to changes in census methodologies, the results of the 2001 census are not directly comparable to the results of prior censuses. This problem has been mitigated somewhat in this work, so that intercensus changes from 1991 to 2001 were computed based on a comparison of the total population in 1991 and permanent residents of settlements (column 3) from the 2001 Census. ${ }^{2}$ 
With reference to the spatial scheme for analysis, it is worthwhile noting the in the administrative-territorial sense, Lika is divided into two counties. The bulk of its territory, over $81 \%$ of the region's total surface, is encompassed by Lika-Senj County with its seat in Gospić, while the remaining $19 \%$ of its surface is in Zadar County. ${ }^{3}$ As spatially-planned units of regional coordination (Rogić, 1996), counties are the optimum spatial units for conducting research into contemporary developmental processes in Croatia's broader territory, but not for regions such as Lika. A more appropriate choice for analysis of demographic development within a spatial unit of this size are its sub-regions (five spatial units $)^{4}$ and local self-government units, i.e. the territories of towns and municipalities based on current administrative-territorial structure (13 spatial units). ${ }^{5}$

This approach, periodization and spatial layout for analysis facilitate a detailed view into the chronological pulsation of differences in the demographic development of Lika, and the consequences of long-term immigration and wartime events in the first half of the 1990s on the contemporary dynamics and structure of the population in the area being examined.

\section{RESULTS OF THE ANALYSIS}

\section{Demographic development of Lika up to the mid-twentieth century to the be- ginning of the $1990 \mathrm{~s}$}

A fundamental characteristic of demographic development in Croatia from the midtwentieth century to the beginning of the 1990s has been the mild but continual growth in its population. From 3,779,858 inhabitants in 1948, by 1991 the population grew to $4,784,265$. This means that over the course of 43 years, there was a total increase of $1,004,407$ inhabitants, or about one quarter of the population (26.6\%). Average annual growth of only 23,358 inhabitants, or a rate of 0.62 , indicates that this is a relatively modest pace of demographic growth.

In contrast, Lika during this period experienced continuous and generally very drastic depopulation. The census of 1948 registered 128,976 people living in the region, while in 1991 there were only 82,883 inhabitants. Therefore, during the period being examined, there was a demographic regression of 46,093 inhabitants, or more than a third (35.7\%) of the total number of inhabitants from 1948.

Here there are considerable differences in the intensity of depopulation between smaller spatial units, ranging from $-28.8 \%$ in Central Lika to $-44.7 \%$ in Southern Lika. Below average depopulation was only recorded in Ličko Pounje, while Krbava and Gacka are in the group of sub-regions with above-average overall depopulation rates during the 1948-1991 period. (Fig. 2).

The most extensive reduction in the population of Lika occurred during the 1970s (by 16,313 inhabitants, or $15.5 \%$ of the total population in 1971). This is followed by the 1960s (with 11,667 inhabitants, or approximately $10 \%$ of the total population in 1961). During these two decades alone, the population declined by approximately one fourth of the region's total population in 1961. 


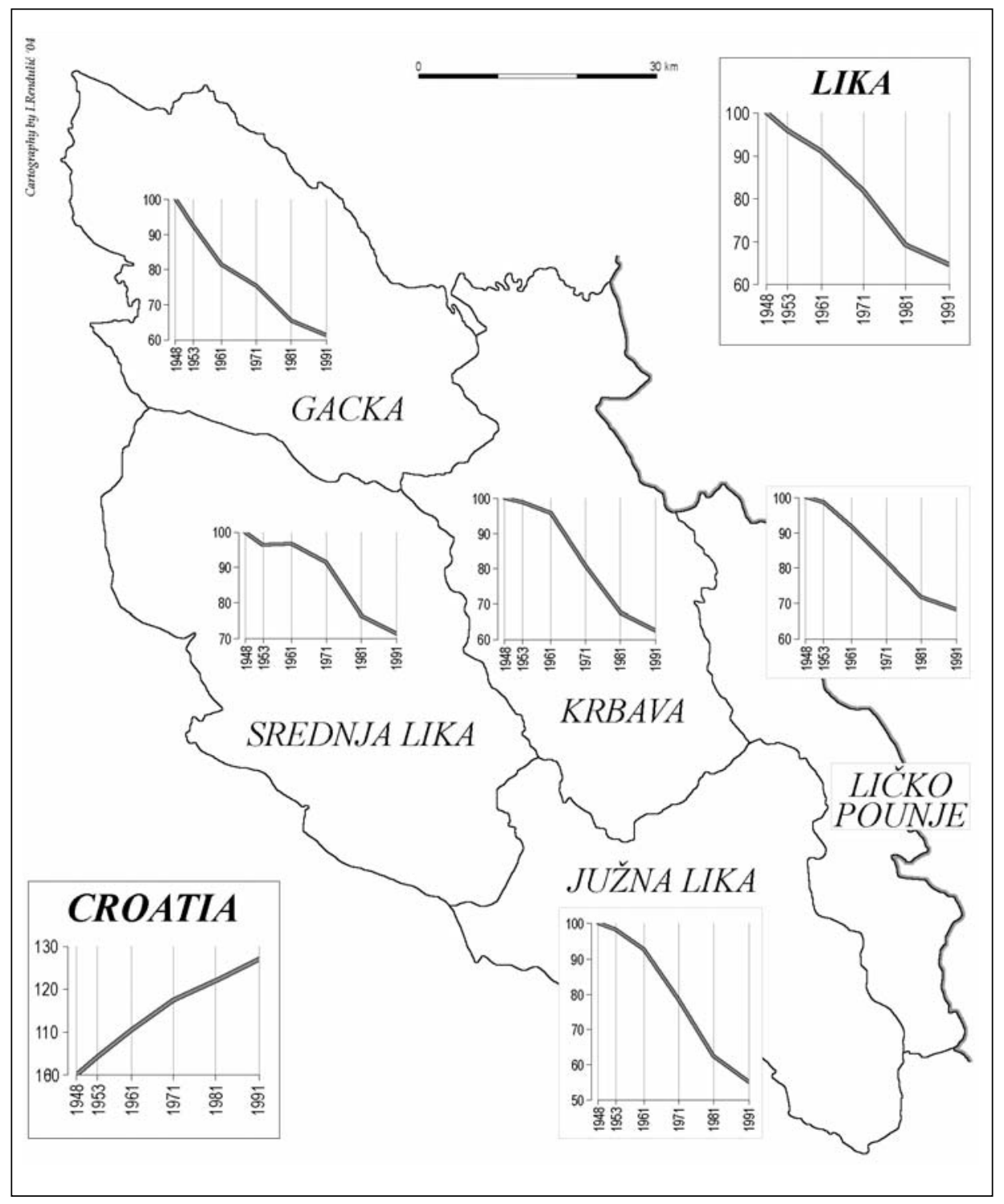

Fig. 2. Population trends in Croatia. Lika and Lika's sub-regions, 1948-1991

Sl. 2. Kretanje broja stanovnika u Hrvatskoj, Lici i subregijama Like 1948.-1991.

Such striking depopulation since the beginning of the 1960s resulted from the intense rural exodus from the region, caused by Lika's lag in regional development in Croatia under conditions of the most dynamic polarized development in the country and employment abroad. The intensity and pulsation of emigration at the time are reflected in the net migration balance in Lika's municipalities from 1961 to 1991 . The almost negligible immigration makes the migration balance almost identical to the total number 
of emigrants from the region and its municipalities during the period under examination. These data convincingly testify to the fact that demographic development in Lika from the beginning of the 1960s to the beginning of the 1990s is fundamentally characterized by emigration (Table 1).

Tab. 1. Net migration balance in Lika's municipalities, 1961-1991.

Tab. 1. Netto saldo migracija u općinama Like 1961.-1991.

\begin{tabular}{|l|c|c|c|c|c|c|c|c|}
\hline \multirow{3}{*}{ Municipality } & \multicolumn{7}{|c|}{ Migration balance } \\
\cline { 2 - 9 } & \multicolumn{2}{|c|}{$1961-1971$} & \multicolumn{1}{c|}{$1971-1981$} & \multicolumn{1}{c|}{$1981-1991$} & \multicolumn{2}{c|}{$1961-1991$} \\
\cline { 2 - 9 } & Abs. & $\%$ & \multicolumn{1}{c|}{ Abs. } & \multicolumn{1}{c|}{$\%$} & \multicolumn{1}{c|}{ Abs. } & \multicolumn{1}{c|}{$\%$} & \multicolumn{1}{c|}{ Abs. } & \multicolumn{1}{c|}{$\%$} \\
\hline Gospić & $-5,186$ & $(-12.9)$ & $-6,070$ & -16.2 & -753 & $(-2.4)$ & $-12,012$ & -29.9 \\
\hline Otočac & $-5,068$ & $(-15.1)$ & $-4,283$ & -12.6 & -790 & $(-3.0)$ & $-10,141$ & -30.3 \\
\hline Titova Korenica & $-3,497$ & $(-20.3)$ & $-2,224$ & -15.1 & -551 & $(-4.5)$ & $-6,272$ & -36.3 \\
\hline Gračac & $-3,661$ & $(-20.2)$ & $-2,857$ & -19.2 & -972 & $(-8.2)$ & $-7,490$ & -42.6 \\
\hline Donji Lapac & $-1,889$ & $(-17.6)$ & $-1,294$ & -13.5 & -167 & $(-2.0)$ & $-3,350$ & -31.2 \\
\hline LIKA & $-19,304$ & $(-16.2)$ & $-16,728$ & -15.6 & $-3,233$ & $(-3.6)$ & $-39,265$ & -32.9 \\
\hline
\end{tabular}

Source: Pejnović, 1991: 73.

A particularly indicative fact pertaining to the impact of the mechanical population trends of the time on Lika's demographic and regional development is that during the 30 -year period being examined approximately 40,000 inhabitants left the region, which is approximately one third of its total 1961 population. The most intense rural exodus occurred during the 1960s, when approximately one half of the total number of emigrants during the 1961-1991 period left the region. All of Lika's sub-regions (the municipalities of the time) were beset by some greater or lesser degree of emigration, wherein those in western Lika (Gospić and Otočac) account for higher numbers, while those from eastern Lika (Gračac, Titova Korenica, Donji Lapac) lead in terms of share of emigrants during that thirty-year period. ${ }^{6}$

Intense emigration has left deep, unfavorable consequences on the age structure and natural growth of the region's population. The loss of the population's younger contingent in its reproductive years, and the advanced process of aging have resulted in natural decline already by the mid-1970s. The number of deaths surpassed the number of live births in Southern Lika, Krbava and Central Lika already in the first half of that decade, while by the second half Gacka and Ličko Pounje joined them.

The unfavorable demographic tendencies, marked by a growing negative intensity in natural trends under the conditions of further emigration, were correspondingly reflected in Lika's general population trends. ${ }^{7}$ So it was already during the 1960s and 1970s the region joined a category of exodus zones with drastic depopulation trends $\left(\mathrm{E}_{3}\right)$, while during the 1980s it became an exodus zone exhibiting a dying-off trend $\left(\mathrm{E}_{4}\right)$. Due to the earlier appearance and progression of negative natural trends, Southern Lika, Krbava and Central Lika were already beset by demographic dying in the 1970s. Over the next decade, this process of demographic dying expanded to the other two sub-regions, Gacka and Ličko Pounje (Fig. 3). 


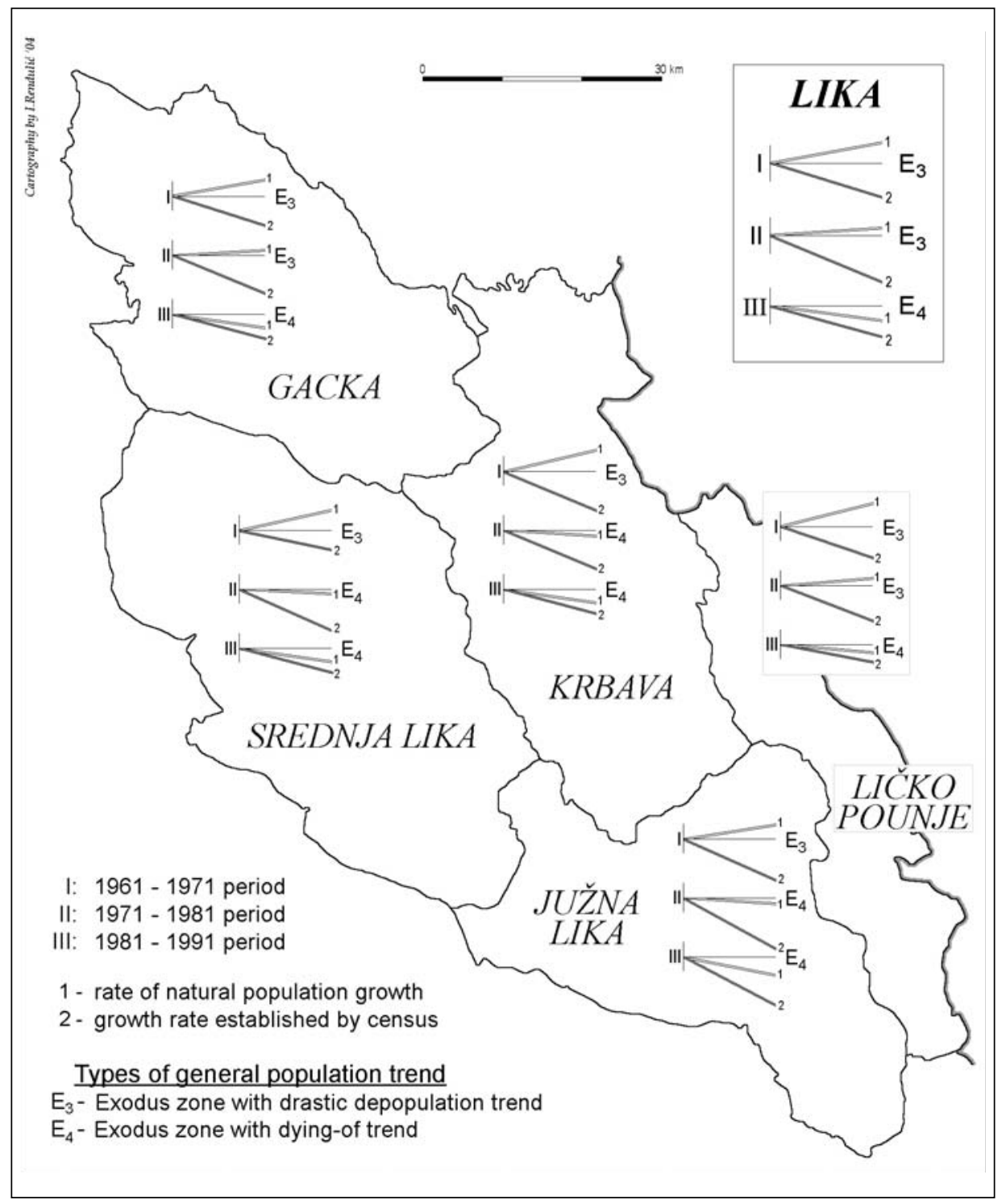

Fig. 3. Types of general population trends in Lika and its sub-regions, 1961-1991

Sl. 3. Tipovi općeg kretanja stanovništva u Lici i subregijama Like 1961.-1991.

Due to this orientation and the growing negative intensity of demographic processes, already during the 1970s Lika stood out in Croatia as a region with adverse demographic developmental features. During the last prewar intercensus period, 1981-1991, it was the only Croatian region in which all sub-regions and most settlements were undergoing a process of demographic dying (Pejnović, 1996). 


\section{Demographic Development in Lika from 1991 to 2001}

The extremely adverse structural and biodynamic features of the population by the beginning of the 1990s, followed by the devastating effects of the war during the first half of that decade caused the halving of Lika's population during the last intercensus period. This is reflected in the highest rate of depopulation among Croatia's regions from 1991 to 2001 (Table 2).

Tab. 2. Changes in population in local government units (administrative towns and municipalities) in Lika, 1991-2001

Tab. 2. Promjena broja stanovnika u jedinicama lokalne samouprave (upravnim gradovima i općinama) Like 1991.-2001.

\begin{tabular}{|l|c|c|c|c|}
\hline \multirow{2}{*}{$\begin{array}{l}\text { Administrative towns (T) } \\
\text { and municipalities (M) }\end{array}$} & \multicolumn{2}{|c|}{ Population } & \multicolumn{2}{c|}{$\begin{array}{c}\text { Population changes } \\
\text { 1991-2001 }\end{array}$} \\
\cline { 2 - 5 } & 1991 & 2001 & \multicolumn{1}{|c|}{ Abs. } & $\%$ \\
\hline - T. Gospić & 22,026 & 12,961 & $-9,065$ & -41.16 \\
\hline - T. Otočac & 16,113 & 10,409 & $-5,704$ & -35.4 \\
\hline - M. Brinje & 6,035 & 4,107 & $-1,928$ & -31.95 \\
\hline - M. Donji Lapac & 4,603 & 1,880 & $-2,723$ & -59.16 \\
\hline - M. Gračac & 11,167 & 3,920 & $-7,247$ & -64.9 \\
\hline - M. Lovinac & 3,054 & 1,096 & $-1,958$ & -64.11 \\
\hline - M. Perušić & 5,648 & 3,493 & $-2,155$ & -38.16 \\
\hline - M. Plitvička Jezera & 7,156 & 4,661 & $-2,495$ & -34.78 \\
\hline - M. Udbina & 4,628 & 1,643 & $-2,985$ & -64.5 \\
\hline - M. Vrhovine & 2,453 & 905 & $-1,548$ & -63.11 \\
\hline Total: LIKA & 82,883 & 45,075 & $-37,808$ & -45.62 \\
\hline
\end{tabular}

Source: Census 1991. Dokumentacija 884, Zagreb: Dražavni zavod za statistiku, 1994 Census 2001. Population based on presence/absence by settlement, www.dzs.hr

The absolutely most extensive depopulation occurred in local government units with the largely populations at the beginning of the 1990s. Primarily this encompasses the territory of the Town of Gospić, which accounts for almost one fourth of the total demographic regression shown. It is followed by the Gračac Municipality and the territory of the Town of Otočac.

It is difficult to ascertain precisely how much of the recorded decline in Lika's population is due to inherited negative demographic processes and how much to the recent war. However, relative differences in depopulation between individual cities and municipalities indicate that the principal factor was in fact wartime events. The latter point is confirmed by the fact that the highest rates of decline in the population occurred in those parts of eastern and southern Lika hardest hit by the war (Fig. 4). 


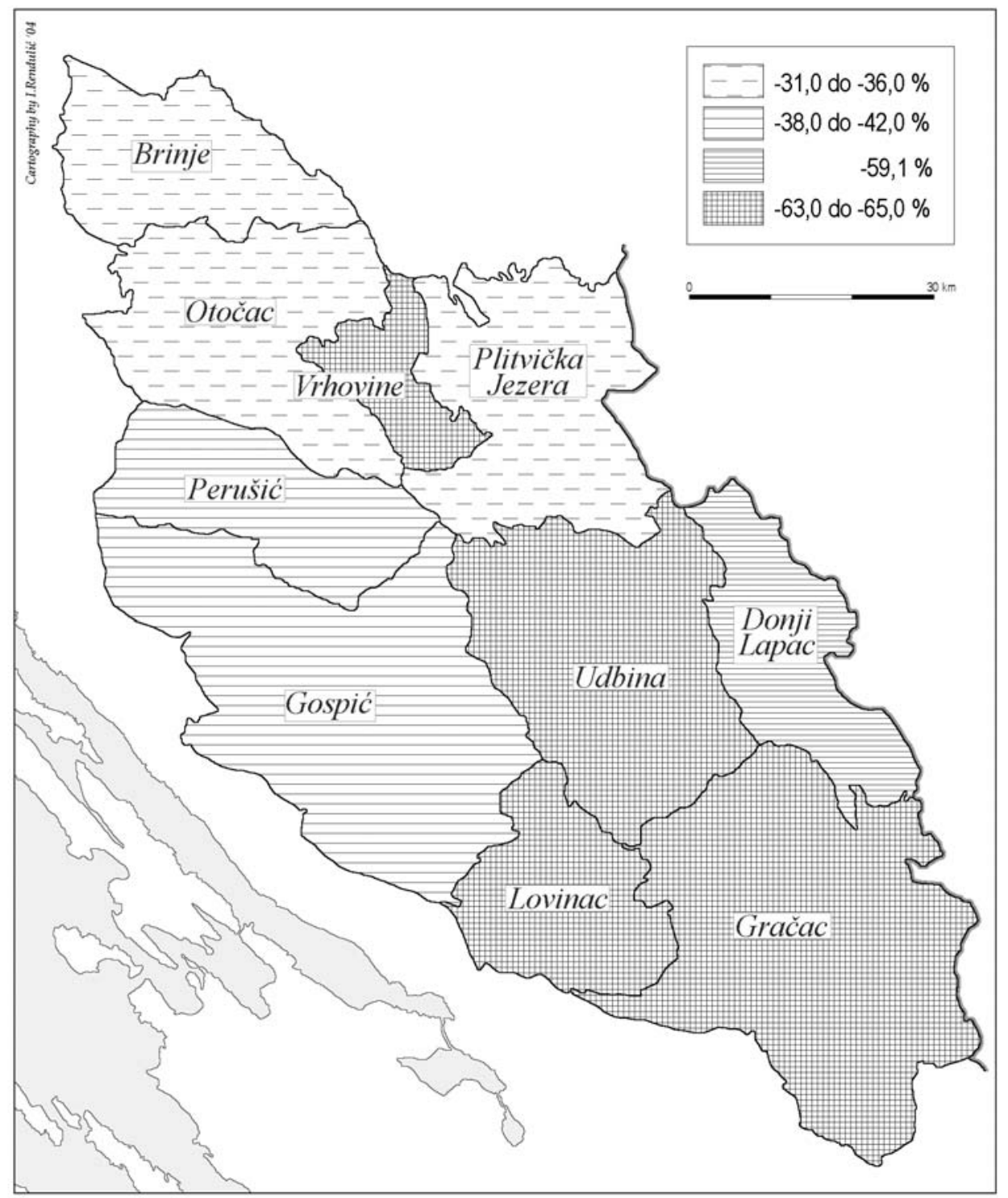

Fig. 4. Intensity of depopulation in local government units (towns and municipalities) in Lika, 1991-2001 Sl. 4. Intenzitet depopulacije u jedinicama lokalne samouprave (gradovima i općinama) Like 1991.-2001. 
Due to its assumed key importance as nodes of potential revitalization, contemporary demographic development of the region's main central settlements merits particular attention. An analysis of trends in population figures in focal points of administrative towns and municipalities in the region from 1991 to 2001 indicates that greater or lesser depopulation encompassed all centers. Gospić is ranked first in terms of absolute decline in its population, as in the 2001 census approximately one third less inhabitants were registered than at the beginning of the 1990s (Table 3).

Tab. 3. Population changes in the principal central settlements of administrative towns and municipalities in Lika, 1991-2001

Tab. 3. Promjena broja stanovnika u glavnim središnjim naseljima upravnih gradova i općina Like 1991.-2001.

\begin{tabular}{|l|r|r|r|c|}
\hline \multirow{2}{*}{ Central settlements } & \multicolumn{2}{|c|}{ Population } & \multicolumn{2}{c|}{$\begin{array}{c}\text { Population change } \\
\text { 1991-2001 }\end{array}$} \\
\cline { 2 - 5 } & 1991 & 2001 & \multicolumn{1}{c|}{ Abs. } & $\%$ \\
\hline - Gospić & 9,025 & 6,075 & $-2,950$ & -32.69 \\
\hline - Otočac & 5,404 & 4,353 & $-1,054$ & -19.45 \\
\hline - Brinje & 2,049 & 1,707 & -342 & -16.69 \\
\hline - Donji Lapac & 1,791 & 812 & -979 & -54.66 \\
\hline - Gračac & 4,101 & 2,687 & $-1,414$ & -34.48 \\
\hline - Lovinac & 533 & 288 & -245 & -45.97 \\
\hline - Perušić & 1,316 & 957 & -359 & -27.28 \\
\hline - Korenica & 1,716 & 1,563 & -153 & -8.92 \\
\hline - Udbina & 1,162 & 735 & -427 & -36.75 \\
\hline - Vrhovine & 873 & 451 & -422 & -48.34 \\
\hline
\end{tabular}

Source: Census 1991. Dokumentacija 884,Zagreb: Dražavni zavod za statistiku, 1994 Census 2001. Population based on presence/absence by settlement, www.dzs.hr

This demographic regression in the leading urban centers of the region has multiple adverse effects on demographic and regional development in Lika and Lika-Senj County. The insufficient development of the leading central settlements, including the low degree of demographic concentration, was one of the fundamental causes regional destabilization up to the beginning of the 1990s. With a population of slightly over 6,000, Gospić is currently, after Krapina and Pazin, the smallest county seat in Croatia. This seriously brings into question the possibility of its positive influence on stabilization of settlement patterns in Lika, i.e. the spatial-functional integration of Lika-Senj County.

This decline in the population was correspondingly reflected in the decline in the overall relative population density of Lika and its smaller spatial units. With 8.4 persons $/ \mathrm{km}^{2}$, this is currently the lowest population density of any Croatian region, nine times lower than the national average ( 78.5 persons $/ \mathrm{km}^{2}$ in 2001). A more thorough analysis of population density indicates considerable differences between local government units, wherein individual sections of the region exhibit the features of genuine sub-ecumenes (Fig. 5). 


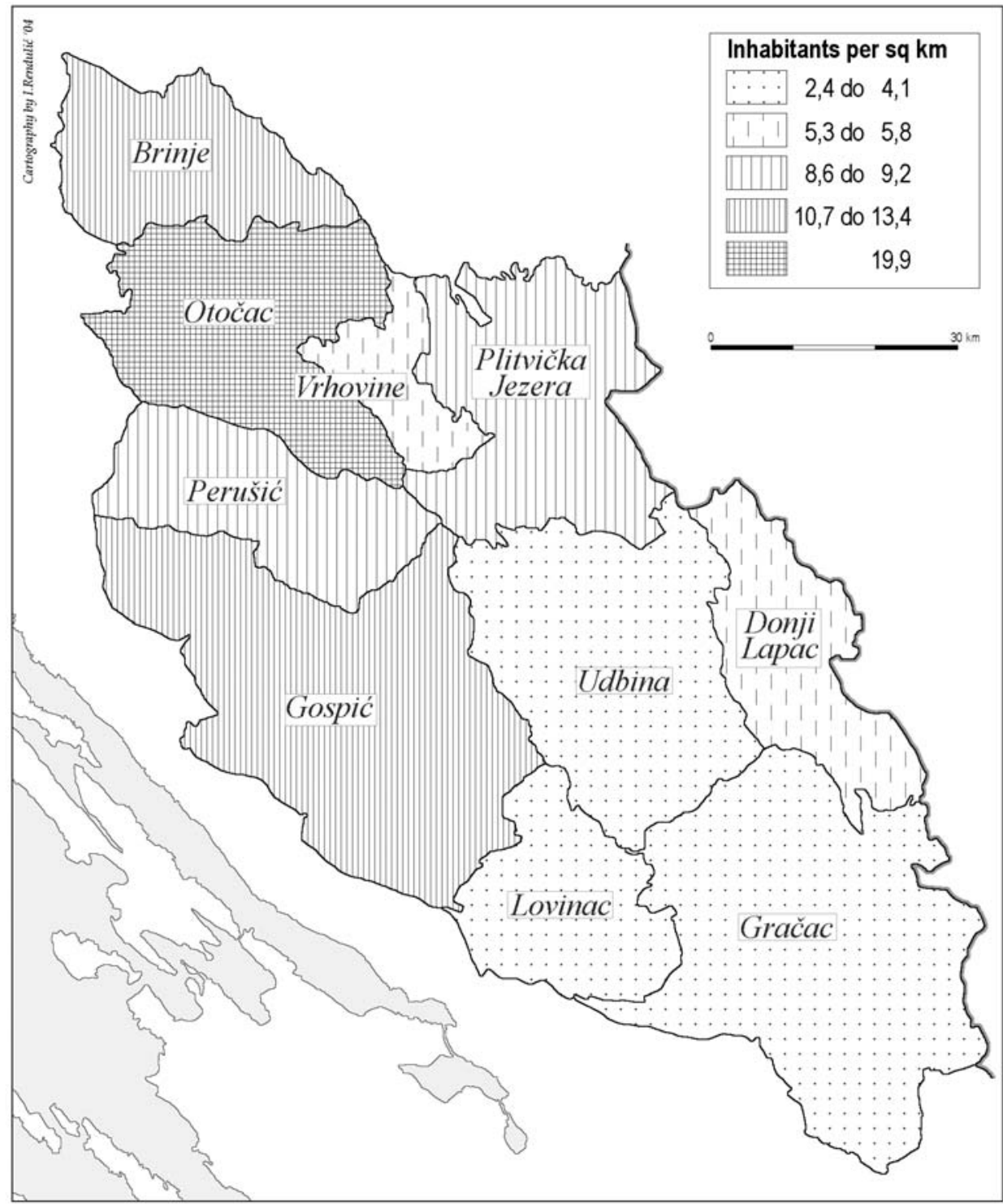

Fig. 5. General relative population density in local government units (town and municipalities) in Lika in 2001 Sl. 5. Opća relativna gustoća naseljenosti u jedinicama lokalne samouprave (gradovima i općinama) Like 2001. godine

Long-term spatial mobility outside of the region, from the traditional exodus due to agrarian overpopulation, through emigration under peripheral conditions after the Second World War, to the wartime exodus of the 1990s, had a cumulative effect, as seen in accelerated aging processes in the population. A result is that Lika today has the oldest 
population among Croatia's regions. The depth of the crisis features of the biological composition of its population reflects the degree of aging, according to which all local government units are characterized by the extreme and most negative type of population age structure (7), with features of extremely deep age (Table 4).

Tab. 4. Aging indicators ${ }^{8}$ in local government units (administrative towns and municipalities) in Lika in 2001

Tab. 4. Pokazatelji ostarjelosti ujedinicama lokalne samouprave (upravnim gradovima iopćinama) Like 2001. godine

\begin{tabular}{|l|c|c|c|}
\hline \multirow{2}{*}{$\begin{array}{l}\text { Administrative towns (T) } \\
\text { and municipalities (M) }\end{array}$} & \multicolumn{2}{|c|}{ Degree of aging } & \multirow{2}{*}{$\begin{array}{c}\text { Share of elderly } \\
\text { ( } \mathbf{6 0} \text { years) }\end{array}$} \\
\cline { 2 - 3 } & Type & Features & 28.54 \\
\hline T. Gospić & 7 & extremely deep age & 27.76 \\
\hline T. Otočac & 7 & extremely deep age & 32.07 \\
\hline M. Brinje & 7 & extremely deep age & 36.57 \\
\hline M. Donji Lapac & 7 & extremely deep age & 31.31 \\
\hline M. Gračac & 7 & extremely deep age & 53.24 \\
\hline M. Lovinac & 7 & extremely deep age & 42.53 \\
\hline M. Perušić & 7 & extremely deep age & 27.95 \\
\hline M. Plitvička Jezera & 7 & extremely deep age & 43.70 \\
\hline M. Udbina & 7 & extremely deep age & 34.08 \\
\hline M. Vrhovine & 7 & extremely deep age & 36.45 \\
\hline Total: LIKA & 7 & extremely deep age & \\
\hline
\end{tabular}

Source: Census 2001. Population according to sex and age by settlement. www.dzs.hr

The extremely detrimental age structure is exacerbated by the fact that in Lika as a whole and in half of its local government unit over one third of the population in 2001 was elderly ( $>60$ years). The share of the elderly in some municipalities (Udbina and Perušić) was over $42 \%$, while in the Lovinac Municipality the elderly even account for a simple majority of the population (53.2\%).

Slightly more propitious features in the population's age structure can be found in the central settlements of administrative towns and municipalities. This primarily pertains to those in which a considerable number of Croats from Bosnia-Herzegovina were settled in the mid-1990s, mainly in Gračac, Korenica, Udbina, Donji Lapac and Vrhovine, and in Lički Osik. Thanks to this immigration of younger populations, the age structure in the relatively better developed municipal seats, such as Gračac and Korenica, belong to type 5 , with very deep aging features. ${ }^{9}$ In contrast, such resettlement had no significant impact in the age structure of the population in the seats of rural municipalities such as Udbina and Donji Lapac (Table 5). 
Tab. 5. Aging indicators in the central settlements of administrative towns and municipalities in Lika in 2001 Tab. 5. Pokazatelji ostarjelosti u glavnim središnjim naseljima upravnih gradova i općina Like 2001. godine

\begin{tabular}{|l|c|c|c|}
\hline \multirow{2}{*}{\begin{tabular}{c}
\multirow{2}{*}{$\begin{array}{c}\text { Central } \\
\text { settlement }\end{array}$} \\
\cline { 2 - 3 }
\end{tabular}} & Type & Degree of aging & $\begin{array}{c}\text { Share of elderly } \\
\text { (> 60 years) }\end{array}$ \\
\hline - Gospić & 6 & Features & 22.74 \\
\hline - Otočac & 6 & exceptionally deep old age & 19.76 \\
\hline - Brinje & 7 & extremely deep old age & 25.93 \\
\hline - Donji Lapac & 7 & extremely deep old age & 28.04 \\
\hline - Gračac & 5 & extremely deep old age & 18.15 \\
\hline - Lovinac & 7 & extremely deep old age & 53.24 \\
\hline - Perušić & 7 & extremely deep old age & 28.90 \\
\hline - Korenica & 5 & very deep old age & 15.54 \\
\hline - Udbina & 7 & extremely deep old age & 25.75 \\
\hline - Vrhovine & 7 & extremely deep old age & 34.08 \\
\hline
\end{tabular}

Source: Census 2001. Population according to sex and age by settlement. www.dzs.hr

The advanced aging process is directly reflected in the growing intensity of negative natural growth, which is one of the basic features of Lika's recent demographic development. This is above all reflected in the numerical indicator showing that over a seven-year period, 1996-2002, the number deaths in the region surpassed the number of live births by almost 2,000. All local government units are recording negative natural trends, and in terms of absolute natural depopulation values, the administrative towns of Gospić and Otočac rank highest, while the least adverse ratio between deaths and live births can be found in the municipalities of Udbina and Lovinac (Table 6).

Tab. 6. Natural population trends in local government units (administrative towns and municipalities) in Lika, 1996-2002

Tab. 6. Prirodno kretanje stanovništva u jedinicama lokalne samouprave (upravnim gradovima i općinama) Like 1996.-2002.

\begin{tabular}{|l|r|c|c|c|}
\hline \multirow{2}{*}{$\begin{array}{l}\text { Administrative towns (T) } \\
\text { and municipalities (M) }\end{array}$} & \multicolumn{2}{|c|}{ Natural population trends, 1996-2002 } & \multirow{2}{*}{$\begin{array}{c}\text { Vital index } \\
\text { (No. of live births for } \\
\text { each 100 deaths }\end{array}$} \\
\cline { 2 - 4 } & Live births & Deaths & Natural trends & 65.4 \\
\hline T. Gospić & 964 & 1,475 & -511 & 66.0 \\
\hline T. Otočac & 739 & 1,119 & -380 & 45.1 \\
\hline M. Brinje & 226 & 501 & -275 & 39.4 \\
\hline M. Donji Lapac & 56 & 142 & -86 & 86.8 \\
\hline M. Gračac & 283 & 326 & -43 & 34.2 \\
\hline M. Lovinac & 54 & 158 & -104 & 40.4 \\
\hline M. Perušić & 231 & 572 & -341 & 96.5 \\
\hline M. Plitvička Jezera & 356 & 369 & -13 & 29.3 \\
\hline M. Udbina & 63 & 215 & -152 & 49.3 \\
\hline M. Vrhovine & 37 & 75 & -38 & 60.8 \\
\hline Total: LIKA & 3,009 & 4,952 & $-1,943$ & \\
\hline
\end{tabular}

Source: Živorođeni po naseljima, tablogram ('Live Births by Settlement, Table'), Zagreb: Državni zavod za statistiku, 1996-2002; Umrli po naseljima, tablogram ('Deaths by Settlement, Table'), Zagreb: Državni zavod za statistiku, 1996-2002. 
Keeping in mind the importance of the role played by central settlements in the potential stabilization of settlements in the region, natural population trends in local government seats merit special attention. Particularly interesting is consideration of the impact of immigration by Croatian refugees from Bosnia-Herzegovina on natural trends in the settlements in which they reside in greater numbers. This is all the more true since a positive impact on these trends was expected, and it is reasonable to assume that this was in fact one of the motives behind their resettlement in this region.

A tabular analysis of natural trends from 1996 to 2002 show that natural growth was only recorded in Gračac and Korenica, while all other centers are characterized by negative natural trends. Gračac does stand out, however, as relatively significant growth was recorded there (Table 7).

Tab. 7. Natural population growth in central settlements of administrative towns and municipalities in Lika, 1996-2002

Tab. 7. Prirodno kretanje stanovništva u glavnim središnjim naseljima upravnih gradova i općina Like 1996.-2002.

\begin{tabular}{|l|c|c|c|c|}
\hline \multirow{2}{*}{$\begin{array}{c}\text { Central } \\
\text { settlement }\end{array}$} & \multicolumn{2}{|c|}{ Natural population trends, 1996-2002 } & \multirow{2}{*}{$\begin{array}{c}\text { Vital index } \\
\text { of live births for } \\
\text { each 100 deaths }\end{array}$} \\
\cline { 2 - 4 } & Live births & Deaths & $\begin{array}{c}\text { Natural } \\
\text { trends }\end{array}$ & 66,6 \\
\hline - Gospić & 459 & 689 & -230 & 94,1 \\
\hline - Otočac & 384 & 408 & -24 & 62,6 \\
\hline - Brinje & 124 & 198 & -74 & 79,2 \\
\hline - Donji Lapac & 38 & 48 & -10 & 176,5 \\
\hline - Gračac & 263 & 149 & 114 & 37,8 \\
\hline - Lovinac & 14 & 37 & -23 & 77,9 \\
\hline - Perušić & 95 & 122 & -27 & 179,4 \\
\hline - Korenica & 174 & 97 & 77 & 56,6 \\
\hline - Udbina & 43 & 76 & -33 & 75,0 \\
\hline - Vrhovine & 24 & 32 & -8 & \\
\hline
\end{tabular}

Source: Živorođeni po naseljima, tablogram ('Live Births by Settlement, Table'), Zagreb: Državni zavod za statistiku, 1996-2002; Umrli po naseljima, tablogram ('Deaths by Settlement, Table'), Zagreb: Državni zavod za statistiku, 1996-2002.

Except for the more developed municipal seats, such as Gračac and Korenica, among the remaining settlements in Lika natural growth was recorded only in Lički Osik (total population 106). Positive natural growth in this settlement is also the result of immigration by a considerable number of Croats from Bosnia-Herzegovina in this- prior to the warleading industrial settlement in Lika. ${ }^{10}$

A more complete picture of more recent tendencies of natural population "growth" in central settlements in Lika is provided by data on their pulsation during the 1996-2002 period (Table 8.). 
Tab. 8 Pulsation (tendencies) of natural population "growth" in central settlements of administrative towns and municipalities in Lika, 1996-2001 (absolute)

Tab. 8. Pulsiranje (tendencije) prirodnog kretanja stanovništva u glavnim središnjim naseljima upravnih gradova i općina Like 1996.-2002.

\begin{tabular}{|l|c|c|c|c|c|c|c|}
\hline \multirow{2}{*}{$\begin{array}{l}\text { Central } \\
\text { Settlements }\end{array}$} & \multicolumn{7}{|c|}{ Natual trends } \\
\cline { 2 - 8 } & 1996 & 1997 & 1998 & 1999 & 2000 & 2001 & 2002 \\
\hline - Gospić & -4 & -41 & -38 & -31 & -33 & -54 & -29 \\
\hline - Otočac & -6 & 17 & -3 & -28 & -2 & 4 & -6 \\
\hline - Brinje & -1 & -12 & -23 & -18 & -1 & -7 & -12 \\
\hline - Donji Lapac & 3 & 2 & 4 & -6 & -4 & -7 & -2 \\
\hline - Gračac & -5 & 13 & 35 & 20 & 28 & 15 & 8 \\
\hline - Lovinac & -3 & -2 & -2 & -4 & -5 & -4 & -3 \\
\hline - Perušić & -6 & 3 & 3 & -3 & -2 & -10 & -12 \\
\hline - Korenica & 7 & 19 & 18 & 17 & 4 & 1 & 11 \\
\hline - Udbina & -3 & 0 & 0 & -5 & -7 & -2 & -16 \\
\hline - Vrhovine & -3 & 1 & 3 & 0 & 0 & -5 & -4 \\
\hline T o t a l: & -21 & 0 & -3 & -58 & -22 & -69 & -65 \\
\hline
\end{tabular}

Source: Živorođeni po naseljima, tablogram ('Live Births by Settlement, Table'), Zagreb: Državni zavod za statistiku, 1996-2002; Umrli po naseljima, tablogram ('Deaths by Settlement, Table'), Zagreb: Državni zavod za statistiku, 1996-2002.

The tabular analysis indicates considerable fluctuations in the population's reproduction, with a growing tendency in the negative intensity of population change in central settlements (from the -20.3 person average from 1997 to 1999 , to -52.3 from 2000 to 2002). The existing problems involved in the biological reproduction of the region's population are particularly reflected in the data on the negative vital balance of the population of Gospic in the period under observation, and in the declining reproduction trend (from the -36.6 person average during 1997-1999 to -38.6 during 2000-2002). Such natural population trends in the leading settlement in Lika and the seat of Lika-Senj County is a more than reliable sign of unabated dissipation of the settlement structure in this part of Croatia.

A more complete estimate of the impact of immigration by Croats from Bosnia on natural trends in Lika's population justifies a more thorough examination of population reproduction in the settlements into which they moved in larger numbers (Table 9).

The data show that immigrants from Bosnia-Herzegovina made an unambiguously positive contribution to natural trends in Lika's population, but with a spatially and chronologically limited effect. Gračac and Lički Osik are in the forefront of this positive natural population change during the period under examination, as it was in these two settlements that most of the immigrants in the region are concentrated, and they are characterized, like Korenica, by a somewhat more favorable age structure (type 5 - very deep old age). In contrast, Udbina, Donji Lapac and Vrhovine are characterized by a smaller number and, on average, older immigrants (age structure is type 7 - extremely deep old age). This is reflected in the overall negative natural "growth" of the population in the aforementioned municipal centers. 
Tab. 9 Pulsation (tendencies) of natural "growth" of the population in settlements in Lika inhabited by larger numbers of Croat immigrants from Bosnia, 1996-2002 (absolute)

Tab. 9. Pulsiranje (tendencije) prirodnog "priraštaja" stanovništva u naseljima Like, u kojima su u znatnijem broju okupljeni doseljeni Hrvati iz Bosne, 1996.-2002. (apsolutno)

\begin{tabular}{|l|c|c|c|c|c|c|c|c|}
\hline \multirow{2}{*}{ Settlement } & \multicolumn{7}{|c|}{ Natual trends } \\
\cline { 2 - 9 } & 1996 & 1997 & 1998 & 1999 & 2000 & 2001 & 2002 & $\begin{array}{c}\text { Total } \\
1996-2002\end{array}$ \\
\hline - Donji Lapac & 3 & 2 & 4 & -6 & -4 & -7 & -2 & -10 \\
\hline - Gračac & -5 & 13 & 35 & 20 & 28 & 15 & 8 & 114 \\
\hline - Korenica & 7 & 19 & 18 & 17 & 4 & 1 & 11 & 77 \\
\hline - Lički Osik & -1 & 9 & 15 & 22 & 24 & 23 & 14 & 106 \\
\hline - Udbina & -3 & 0 & 0 & -5 & -7 & -2 & -16 & -33 \\
\hline - Vrhovine & -3 & 1 & 3 & 0 & 0 & -5 & -4 & -8 \\
\hline T o t a l: & -2 & 44 & 75 & 48 & 45 & 25 & 11 & 246 \\
\hline
\end{tabular}

Source: Živorođeni po naseljima, tablogram ('Live Births by Settlement, Table'), Zagreb: Državni zavod za statistiku, 1996-2002; Umrli po naseljima, tablogram ('Deaths by Settlement, Table'), Zagreb: Državni zavod za statistiku, 1996-2002.

It is notable, however, that immigration of this population only achieved a short-term positive effect on natural trends in the region's population, because with the lifestyle change, the immigrants quickly adapted to the overriding low-natality culture of the area into which they resettled. This is confirmed by the accelerated process of declining natural "growth" from an average of approximately 56 persons during the 1997-1999 period to only 27 in the 2000-2002 period.

Despite the limited impact on natural population growth, the positive aspect of this immigration into Lika is that it primarily involved younger people who brought a relatively large number of children with them. A negative aspect, however, is that these are primarily unskilled and uneducated people, with a poor social and economic status. They have additionally not been sufficiently integrated into their new surroundings (Štambuk, 1998). The successful social integration of these immigrants cannot be considered separately from their greater involvement in labor processes at the local level. This is also a condition for the revitalization of the local government units in which they live. However, due to the overall adverse circumstances, it is unrealistic to expect that they will become a significant developmental force for economic revival in Lika, nor for the ensuing faster regional development of this problematic Croatian region.

\section{DISCUSSION AND CONCLUSION}

The completed analysis confirms the empirical knowledge of a peripheral location as a developmental handicap, which spurs emigration and the associated negative demographic processes. Among the set of factors that cause emigration from peripheries, lagging socio-economic development, or regional development in the wider area, has key importance. This particularly comes to the fore during periods of more complex economic 
development accompanied by intense de-agrarianization. There are limited possibilities for such social restructuring of populations in peripheral zones due to the slower growth of non-agricultural activities and the lack of developed urban centers. This in turn causes a massive rural exodus from such areas, with long-term negative repercussions on demographic and regional development.

The spatial redistribution of the population under the influence of disparities in Croatia's regional development since the mid-twentieth century indicates developmental tendencies characteristic of the transition from the traditional, agrarian society to the modern, industrial and tertiary (service) society (Ruppert et al, 1981). Polarized development (on the one hand) was accompanied by increasing demographic abandonment of rural peripheries (on the other), which was reflected in increasing disparities in Croatia's regional development. This negative developmental process, involving interdependent developmental lagging and emigration from rural areas, proceeded in line with the theory of cumulative causation in the emergence of problem regions (Witherick et al, 2001).

Lika is the most obtrusive example of a periphery in Croatia. Its features are the result of the cumulative effects of its geographic location (at a relative distance from and in the zone of overlap of gravitational influence of developed urban centers: Zagreb, Rijeka and Zadar), a lack of its own regional developmental pole and prevailing rural characteristics (with long retention of the relative importance of agriculture to the economy and the socioeconomic population structure). This also implies the corresponding spatial relationship that manifests itself, among other ways, in the redistribution of the active working population from these peripheral regions to the nodes of polarized development.

As a result of this interdependent influence of its highland/karst natural base, adverse historical/geographic development and peripheral position, this section of Highland Croatia also belongs among the least developed parts of the country. The general developmental index in Lika in 1976 was only $57.9 \%$ of the Croatian average, wherein the developmental lag was particularly apparent in Gacka (former Otočac Municipality) and Southern Lika (former Gračac Municipality), with 51.3\% and 54.3\% of Croatia's average developmental level (Marendić et al, 1982). The developmental problems of the time in this region were deepened by the fact that from the mid-1970s to the mid-1980s, this was the only Croatian region in which all municipalities were categorized as insufficiently developed areas of Croatia. ${ }^{11}$

The planned encouragement of more rapid growth in so-called "economically underdeveloped region," up to the mid-1980s reduced somewhat the lag behind Croatia's average. Thus, in 1983, Lika achieved $73.3 \%$ of Croatia's average developmental level, ranging from $63.9 \%$ in Gračac to $88.2 \%$ in Titova Korenica (Baletić, 1985). Despite this reduction of the lag behind Croatia's regional development, considerable difference between Lika and other parts of the country persisted. The lag behind the leading centers of polarized development in Central Croatia and the Central Croatian Littoral was particularly notable, as these were the principal centers attracting the labor force from this peripheral zone. Thus the average index of general development in the then municipalities of Zagreb (138.9), Rijeka (138.7) and Karlovac (115.5) was $131 \%$ of Croatia's average, which was $77.7 \%$ more than Lika's average development at the time (Baletić, 1985). 
It is understandable that such drastic differences in development over such short distances led to a spatial redistribution of the population between the less developed periphery and developed centers. During the 1960s and 1970s, this assumed the features of a genuine rural exodus, which already caused a process of demographic dying by the 1980s.

Adverse demographic processes additionally intensified the considerable demographic losses influenced by wartime events in 1991-1995. This includes direct war victims (inhabitants who were killed) and wartime refugees, which together had severe negative consequences in demographic and regional development in Lika.

For a better understanding of the intensity and spatial differences in the consequences of the war in the region, it must be noted that until the beginning of the 1990s, Lika was a dual (Serb-Croat/Croat-Serb) ethnic territory. ${ }^{12}$ with the corresponding ethnic composition (49.9\% Serbs, $45.8 \%$ Croats and $4.3 \%$ others). The Serbs accounted for a majority of $83 \%$ in Eastern Lika (Krbava, Southern Lika, Ličko Pounje), while the Croats formed a $64.1 \%$ majority in Western Lika (Central Lika and Gacka). ${ }^{13}$ These differences in shares not only show the numerical relationship between the two principal ethnic groups, rather they also indicate the spatial relations in effect just prior to and during the wartime events of 19911995. Namely, from the very beginning the war led to ethnic homogenization of territory, which forced a considerable number of inhabitants, regardless of ethnicity (Croats in the initial phase, Serbs in the final phase), into a temporary or permanent exodus.

Although there are nothing even remotely close to exact data on the number of such emigrants from Lika, since a portion of them left permanently and a portion returnedand the return process is still not complete, wartime events have had long-term negative consequences on the settlement structure in this region. The latter point is all the more true since the immigration of Croats from Bosnia in the mid-1990s have not nearly compensated the region's demographic losses caused by war. Direct and indirect wartime losses, as well as the negative migration balance in the last intercensus period, had a comprehensive impact in grossly negative demographic processes: intense depopulation (45.6\% in 1991-2001), rapid aging (from $23.4 \%$ in 1991, the share of persons over 60 years of age grew to $36.5 \%$ in 2001) and natural decline in the population (-1,943 persons in 1996-2002).

In consideration of the perspectives for demographic development in Lika, it is necessary to note the great significance of this part of Highland Croatia to the development and spatial-functional integration of Croatia. This importance is based on its intersecting geo-transit location between the three leading hubs of Croatia (something like the country's "transit elbow"), its function as the primary geostrategic core of the country (particularly under new geopolitical conditions), and the relatively considerable indigenous economic resources.

The depth of the crisis features of contemporary demographic development and the size and importance of Lika within Croatia require urgent implementation of incentives to revitalize this region. Given the unfavorable biological composition of the existing settlement structure, demographic and economic revival will only be possible provided that there is considerable immigration by younger and better educated persons. Keeping in mind the direction and intensity of demographic processes, as well as Croatia's excessive polarization, this proposal seems utopian under current circumstances. 
Stabilization of settlement patterns in Croatia's largest problem region is possible only if developmental paradigms and value systems in the country change. The fundamental pillars of such desirable future development should be an explicit orientation toward polycentric development, more balanced regional development and integral development of rural zones. ${ }^{14}$ Among the instruments for more rapid regional development in Lika, particular attention should be accorded to organization of this entire traditional region within the framework of a unified territorial-political unit (Lika-Senj County), multi-sector (most suited to the area) economic development and a hierarchical network of central settlements with Gospić as the prospective regional center (Pejnović, 1996). A key to this stabilization will be the functional elevation of Gospić as a perspective pole for regional development (Marinović-Uzelac, 1992).

An alternative to such regional development and guidance of spatial processes is a continuation of the disastrous processes that have caused Lika's demographic decay. Continuation of existing trends unstoppably leads to the region's demographic desertion, with overall consequences to Croatia's overall development and spatial integration that are difficult to imagine.

\section{NOTES}

1. The potential usefulness of the results of the otherwise exceptionally well-documented work by I. Turčić is diminished by the fact that the demographic analysis was conducted based on the spatial extent of the counties that existed in 1992, which means that it does not correspond to the current territorial and political structure. Namely, the County, City and Municipal Territory Act of 1997 altered the boundaries of 10 of the 20 counties of the time, while the number of counties increased to 21 .

2. For more details see: N. Pokos, 2001, and I. Nejašmić, 2003.

3. Zadar County encompasses a considerable portion of Southern Lika (former Gračac Municipality, without the territory of the Lovinac Municipality) and Ličko Pounje (Una River basin; actually the southern section of the former Donji Lapac Municipality, the so-called Srbski kraj - or 'Serbian district.'). This part of Lika was incorporated into the Zadar administrative territory under wartime circumstances, during 1992, and it remained a part of Zadar County even under the County, City and Municipal Territory Act of 1997.

4. The regional structure of Lika encompasses five sub-regions: Central Lika, Gacka, Krbava, Southern Lika and Ličko Pounje, which until 1992 were organized as a unified municipal territory, or a territory of moderate gravitation. Thus the Gacka sub-region corresponded to the former Otočac Municipality, Krbava corresponded to the Titova Korenica Municipality, Southern Lika to the Gračac Municipality, and Ličko Pounje to the Donji Lapac Municipality. Only Central Lika did not correspond to the territory of the Gospić Municipality, since until the beginning of the 1990s it also included the central section of the Velebit littoral slope (today's Karlobag Municipality).

5. The current local government units in Lika include two administrative towns (Gospić and Otočac) and eight municipalities (Brinje, Donji Lapac, Karlobag, Lovinac, Perušić, Plitvička Jezera, Udbina and Vrhovine).

6. Up to 1991, equally intense emigration from municipalities in which Croats formed a majority of the population (Gospić and Otočac) and in which Serbs formed the majority (Donji Lapac, Gračac and Titova Korenica) quite convincingly refutes the theory of prevailing political motives for emigration ("due to majority dominance or discrimination"), frequently stated at the beginning of the 1990s, and indicates lagging regional development as the fundamental cause for emigration from the region under conditions of rapid social restructuring of the population since the beginning of the 1960s. 
Dane Pejnović - Lika: demographic development under peripheral conditions

7. General population trends are a synthetic indicator of demographic development in a given period. It encompasses natural trends and spatial mobility of a population, which is comprehensively manifested in the population as established by censuses. Based on the typology of M. Friganović (1987), in this work general population trends are discerned which indicate the relationship and impact of natural trends and the population's spatial mobility.

During the period under observation, 1961-1991, Lika and all of its sub-regions were exodus zones with distinct, extremely detrimental demographic developmental features. An exodus zone with a marked depopulation trend (E3) is characterized by natural growth and depopulation, wherein the natural trend rate is lower than the reduction rate established by censuses. An exodus zone with a dying trend (E4) is characterized by negative natural trends and depopulation, wherein the rate of natural decline is less than the reduction established by censuses.

8. Evaluation of the population's age structure was conducted in line with a procedure devised by M. Klemenčić (1990), while determination of the population's degree of aging was determined using the types established by I. Nejašmić (2003). The procedure for evaluating the age structure is based on assigning points to the share of young and elderly populations and adding these values up, which then generates a point indicator of a population's aging. The types consist of seven degrees of aging (1 - at threshold of aging, 2 - aging, 3 - old age, 4 - deep old age, 5 - very deep old age, 6 - exceptionally deep old age and 7 - extremely deep old age).

9. By way of comparison, the age structure in Gračac in 1991 was also type 5, and type 4 in Korenica, with features of deep old age. The same degree of aging was recorded in Udbina, so that at the beginning of the 1990s, these two Krbava centers had the lowest elderly populations among today's central settlements of towns and municipalities in Lika.

10. Novi Lički Osik is an industrial settlement established for strategic reasons (as a perspective driver of Lika's industrialization, among other reasons) between 1948 and 1954. The basic labor functions was fulfilled by the large (for Lika) Marko Orešković metal processing plant which was, with approximately 1,880 employees at the end of the 1980s, the largest industrial enterprise in Lika. The 1991 census in the settlement of Lički Osik (roadside settlement known as "Stari Lički Osik" and the industrial colony "Novi Lički Osik") had a registered population of 2,885. At the end of the war in the mid-1990s, residents from surrounding settlements and approximately 80 Croat families from Bosnia settled in Novi Lički Osik. The result was that in the 2001 Census, the population was 1,946, which indicates depopulation of 939 , or $32.35 \%$. The postwar settlement of younger and reproductively more vital residents had a positive impact on growth during 1996-2002 (a total of 106 inhabitants). The highest growth was recorded during the 1999-2001 period (an average of 23 persons per year), while a notable decline was recorded in 2002 (14 persons).

11. Narodne novine, 33/1978; 31/1981; 17/1986.

12. This term implies "territory of a people in which it secures its long-term existence and with which it has strong emotional bonds as its living space” (Pavić, 1973).

13. Source: Census 1991, Narodnosni sastav stanovništva Hrvatske po naseljima (Ethnic Structure of Croatia's Population by Settlement), Dokumentacija 881, Zagreb, 1992.

14. For more on measures to slow depopulation and possibly revitalize depressed regions, cf. I. Nejašmić (1991: 251-266).

\section{REFERENCES}

Akrap, A., 2002: Prostorni razmještaj stanovništva u Hrvatskoj, in: Hrvatska demografska i demostrateška drama (ed. V. Pavletić). Knjižnica Kritika, Vol. 2, A. G. Matoš d.o.o., Samobor - Udruga «11. siječnja 1972», Zagreb, 32-70.

Baletić,Z., 1985: Razvoj privredno nedovoljno razvijenih krajeva SR Hrvatske (ed. Z. Baletić). Zagreb: Ekonomski institut Zagreb, Republički fond za razvoj privredno nedovoljno razvijenih krajeva SRH, p. 228. 
Friganović, M., 1987: Demogeografija: stanovništvo svijeta. Zagreb: Školska knjiga, p. 271.

Friganović, M. A., 1992: Promjene u dinamici stanovništva Hrvatske 1981.-1991. kao funkcija urbanizacije, Geografski glasnik, 54, 63-74.

Klemenčić, M., 1990: Postupak vrednovanja dobnog sastava stanovništva, Radovi, Vol. 25, br. 25, 73-80.

Koči-Pavlaković, V., 1996: Regionalni ekonomski razvoj graničnih krajeva: teorijske osnove i modeli in: Zbornik radova I. hrvatskoga geografskog kongresa. Zagreb: Hrvatsko geografsko društvo, 351-358.

Marendić, B., Turčić, I., Mates, N., 1982: Mjerenje i analiza razvijenosti općina SR Hrvatske, in: Nedovoljno razvijena područja SR Hrvatske (ed.Z. Baletić, B. Marendić), Zagreb: Ekonomski institut Zagreb, Republički fond za razvoj privredno nedovoljno razvijenih krajeva SRH, Republički zavod za društveno planiranje SRH, 23-43.

Marinović-Uzelac, A., 1992: Regionalizacija iz vidokruga prostornog planiranja, Društvena istraživanja, 1 (Država, regije, regionalni razvoj), Institut za primijenjena društvena istraživanja Sveučilišta u Zagrebu, Zagreb, 69-86.

Nejašmić, I., 1991: Depopulacija u Hrvatskoj: korijeni, stanje, izgledi. Zagreb: Biblioteka Posebna izdanja/ Globus, p. 344.

Nejašmić, I., 2003: Značajke biološkog (demografskog) sastava stanovništva Hrvatske, Hrvatski geografski glasnik, 65/1, 29-54.

Pavić, R., 1973: Osnove opće i regionalne političke geografije, geopolitike i geostrategije, Part II. Zagreb: Fakultet političkih nauka, p. 261.

Pejnović, D., 1991: Opće kretanje stanovništva kao odraz i pokazatelj socijalno-geografske diferencijacije Like, Radovi, 26, 65-77.

Pejnović, D., 1996: Geografski aspekt revitalizacije depopulacijskih i ratom pogođenih područja Hrvatske na primjeru Like, Zbornik I. hrvatskog geografskog kongresa, Zagreb, 255-273.

Pejnović, D., 1999: Lika - an example of socio-geographic change in highland Croatia, Sonaravni razvoj v slovenskih alpah in sosedstvu $=$ Sustainable development in the Slovenian Alps and its neighbouring, Dela, 13, Ljubljana, 317-336.

Pejnović, D., 2003: Socijalno-ekonomska struktura stanovništva kao indikator razlika u regionalnom razvoju Hrvatske, in: Zbornik radova; Regionalno razvojna problematika Bosne i Hercegovine i susjednih zemalja u procesu približavanja Evropskoj uniji, Tuzla: Univerzitet u Tuzli, 49-66.

Pejnović, D., 2004: Depopulacija županija i disparitet u regionalnom razvoju Hrvatske, Društvena istraživanja, no. 4-5 (72-73), 701-726.

Pokos, N., 2003: Metodološke promjene u popisima stanovništva, Hrvatska revija, 1, 29-35.

Rogić, V., 1996: Bitnost problematike regionalizacije i njezin odnos prema županijskoj organizaciji, in: Hrvatske županije kroz stoljeća (ed. F. Mirošević), Zagreb: Školska knjiga, 149-154.

Ruppert, K., Schaffer, F., Maier, J., Paesler, R., 1981: Socijalna geografija. Zagreb: Školska knjiga, p. 159.

Sić, M., 2003: Regional Disparities in Croatia, Geografski glasnik, 65, 5-28.

Turčić, I., 2001: Makroekonomski razvoj županija u Republici Hrvatskoj kroz tri desetljeća (1961/1962. do 1990/1991.), 2. dio, Dugoročne tendencije kretanja stanovništva županija u Republici Hrvatskoj 1961. do 1991., Zagreb: Ekonomski institut - Zagreb, Državni zavod za statistiku, p. 185.

Štambuk, M., 1998: Lika - studija slučaja, in: Duge sjene periferije: prinos revitalizaciji hrvatskoga ruba (ed. I. Rogić, M. Štambuk), Zagreb: Institut društvenih znanosti Ivo Pilar, 44-107.

Witherick, M., Ross, S., Small, J., 2001: A Modern Dictionary of Geography, London: Arnold, p. 293. 


\title{
SAŽETAK
}

\section{Lika: demografski razvoj u uvjetima periferije}

\author{
Dane Pejnović
}

Iako se nalazi gotovo u geometrijskom središtu države, Lika je najizrazitiji primjer periferije u Hrvatskoj. Takve njezine značajke posljedica su rubnog geografskog položaja, na relativnoj udaljenosti i u zoni (međuprostoru) preklapanja gravitacijskog utjecaja razvijenih gradskih središta, Zagreba, Rijeke i Zadra. Rezultat takvog položaja naglašenije su karakteristike ruralnog prostora, obilježenog nedostatkom razvijenijega vlastitog gradskog središta i dugo zadržanim relativnim značenjem poljoprivrede u gospodarstvu i socio-ekonomskoj strukturi stanovništva.

Značajke periferije, u smislu ovisnosti o razvijenim gradskim središtima, dodatno su potencirane trajnim zaostajanjem Like u regionalnom razvoju šireg područja Hrvatske. Ono je rezultat kumulativnog utjecaja više čimbenika, od gorsko-krške prirodne osnove, preko nepovoljnog povijesno-geografskog razvoja (u okviru Vojne krajine) do sporog i nedovoljnog uključivanja u složeniji razvoj zbog nedostatne i/ili neodgovarajuće prometne infrastrukture.

Takave njezine značajke predodredile su taj dio Gorske Hrvatske kao izrazito emigracijski prostor. Više ili manje intenzivno iseljavanje temeljno je obilježje prostorne pokretljivosti njezina stanovništva od početka 1870-ih godina. S obzirom na karakter (uzroke) iseljavanja, u osnovi je moguće izdvojiti tri razdoblja takvog mehaničkog kretanja stanovništva: 1. iseljavanje u uvjetima agrarne prenaseljenosti, odnosno pasivnosti krškog kraja, od početka 1870-ih godina do sredine 20. stoljeća, 2. iseljavanje u uvjetima periferije, odnosno polariziranog razvoja Hrvatske, od početka 1950-ih do 1990-ih godina, i 3. ratom uzrokovani eksodus stanovništva tijekom prve polovice 1990-ih godina.

U radu je pobliže razmotren demografski razvoj Like u uvjetima periferije, od sredine 20. stoljeća do 2001. godine. Zbog diferenciranih uzroka iseljevanja, kao i njihova utjecaja na kretanje broja stanovnika, biološki sastav i prirodnu dinamiku stanovništva regije, izdvojena su dva različita razdoblja demografskog razvoja: od sredine 20. stoljeća do početka 1990-ih godina i posljednje međupopisno razdoblje, 1991.-2001.

Demografski razvoj Like od sredine 20. stoljeća do početka 1990-ih godina obilježen je kontinuiranom i uglavnom izrazitom depopulacijom. U razdoblju 1948-1991. broj stanovnika regije smanjio se za oko 46.000, odnosno za više od trećine $(35,7 \%)$. Do najveće depopulacije došlo je tijekom 1970-ih i 1960-ih godina, dok je ukupno najveće smanjenje među subregijama zabilježeno u Južnoj Lici (-44,7\%).

Intenzivna depopulacija od početka 1960-ih godina posljedica je ruralnog egsodusa iz regije, uzrokovanog zaostajanjem Like u regionalnom razvoju Hrvatske u uvjetima najdinamičnijeg polariziranog razvoja zemlje i zapošljavanja u inozemstvu. Neto saldo migracija pokazuje da je oko polovice od ukupnog broja iseljenika 1961.-1991. regiju napustilo tijekom 1960-ih godina, a daljnjih oko 43\% 1970-ih godina. Pritom je zapadna Lika prednjačila većim brojem, a istočna relativno većim iseljavanjem stanovništva.

Intenzivno iseljavanje ostavilo je duboke, nepovoljne posljedice u dobnom sastavu i prirodnom kretanju stanovništva Like. Gubitak mlađih kontingenata stanovništva i uznapredovali proces starenja rezultirali su prirodnim padom već sredinom 1970-ih godina. To je imalo za posljedicu da je s obzirom na opće kretanje stanovništva regija već 1960-ih i 1970-ih godina pripadala eksodusnim prostorima $\mathrm{s}$ trendom izumiranja $\left(\mathrm{E}_{3}\right)$, a 1980-ih godina eksodusnim 
prostorima s trendom izumiranja $\left(\mathrm{E}_{4}\right)$. Najranije su demografskim izumiranjem zahvaćene Južna Lika, Krbava i srednja Lika, već 1970-ih godina. U razdoblju 1981.-1991. Lika je bila jedina hrvatska regija u kojoj su sve manje prostorne cjeline (subregije) bile zahvaćene demografskim izumiranjem.

Nepovoljna obilježja demografskog razvoja do početka 1990-ih dodatno su intenzivirana učincima rata tijekom prve polovice tog desetljeća. Rezultat toga je smanjenje broja stanovnika 1991.-2001. za skoro 38.000, odnosno oko 46\%. Pritom postoje znatne prostorne razlike u intenzitetu depopulacije; tako smanjenjem broja stanovnika prednjače grad Gospić, zatim općina Gračac, te grad Otočac, dok relativno najveću depopulaciju bilježe općine Gračac, Udbina i Lovinac. To se odrazilo u odgovarajućem smanjenju opće relativne gustoće naseljenosti u regiji $\left(8,4 \mathrm{st} / \mathrm{km}^{2} 2001\right.$.), pri čemu pojedini dijelovi imaju značajke prave subekumene. Nepovoljnost recentnog demografskog razvoja dodatno ističe i podatak da veću ili manju depopulaciju bilježe glavna središnja naselja u svim jedinicama lokalne samouprave, s rasponom od oko $-9 \%$ u Korenici do čak oko $-55 \%$ u Donjem Lapcu.

Takvom kretanju broja stanovnika odgovara i suvremeni biološki sastav stanovništva Like, čije je temeljno obilježje krajnje uznapredovali proces starenja. Odražava ga krajnje duboka starost stanovništva regije i svih njezinih manjih prostornih cjelina. Više od trećinu $(36,5 \%)$ stanovništva Like 2001.činilo je staro stanovništvo (>60 godina), pri čemu je u općini Lovinac ta dobna skupina činila natpolovičnu većinu stanovništva.

Izrazit proces starenja odražava se u negativnom prirodnom kretanju stanovništva Like (oko 2.000 manje živorođenih od broja umrlih u razdoblju 1996.-2002.). Dubinu problema reprodukcije stanovništva posebno podcrtava podatak da negativno prirodno kretanje bilježe sve jedinice lokalne samouprave u regiji, pri čemu broj umrlih u pojedinim ruralnim općinama nadmašuje broj živorođenih za 3-4 puta (Udbina, Lovinac). Među središnjim naseljima priraštaj u promatranom razdoblju bilježe samo Gračac i Korenica, a od ostalih naselja Lički Osik, u kojima su u znatnijem broju okupljeni doseljeni Hrvati iz Bosne. Njihovo naseljavanje pozitivno se odrazilo na prirodno kretanje stanovništva Like, ali s prostorno i vremenski ograničenim učinkom.

Dubina kriznih obilježja suvremenog demografskog razvoja Like ozbiljno dovodi u pitanje mogućnost revitalizacije tog prostora. Veličina ( $9,3 \%$ površine Hrvatske) i značenje regije kao križišnog geoprometnog prostora i geostrateške regije jezgre Hrvatske nalažu potrebu neodgodivog poduzimanja mjera s ciljem zaustavljanja negativnih procesa.

Received (Primljeno): 2004 - 11 - 8

Accepted (Prihvaćeno): 2004 - 11 - 29

Dane Pejnović, Ph. D., associate professor Department of Geography, Faculty of Science Marulićev trg 19, 10000 Zagreb,

Hrvatska/Croatia dapejno@geog.pmf.hr 